\title{
ŠIAULIU MIESTO CENTRINĖ DALIS AR URBANISTIKOS PAVELDO SAUGOTINOS TERITORIJOS?
}

\author{
Algis Vyšniūnas \\ Urbanistikos katedra, Vilniaus Gedimino technikos universitetas, \\ Pylimo g. 26/Trakug. 1, 01132 Vilnius, Lietuva \\ El.paštas: algis.vysniunas@gmail.com; urbkat@vgtu.lt
}

Iteikta 20101004

\begin{abstract}
Santrauka. 1969 m. sausio 27 d. LSSR kultūros ministro ir LSSR Ministrų tarybos valstybinio statybos reikalų komiteto pirmininko įsakymu Nr. 37/16 paskelbtas Lietuvos urbanistinių paminklų sąrašas. Taigi 62 miestai ir miesteliai buvo paskelbti vietos reikšmės urbanistikos paminklais, bet paminklų sąraše nẻra Šiaulių miesto. Nẻra ir 1980 m. patikslintame Lietuvos urbanistinių paminklų sąraše. Iš atliktos esamos padèties analizès, ịvertinus urbanistinės plètros poreikị ir potencialą, paaiškèjo, kad Šiaulių mieste yra labai aiški istoriškai susiklosčiusi urbanistinè struktūra, kuri, tinkamai respektuota, gali būti traktuojama kaip urbanistinio paveldo teritorija. Taip pat atlikta mokslinių darbų, galimybių studijų, teritorijų planavimo dokumentų, konkursinių projektų ir pan. analizė ne tik tą patvirtino, bet ir parodè būdus, kaip tą padaryti. Šiaulių miesto centrinès dalies urbanistinès plètros potencialas didelis, bet labai svarbus pletros ir apsaugos balansas. Straipsnio pobūdis - taikomasis, nes sukurtas rekomendacijų blokas, kuris leidžia parengti rekomendacinių užstatymo principų ir rodiklių kompleksą, kuriuo remiantis galima būtų rengti Šiaulių miesto centrinės dalies detaliojo plano reglamentus.
\end{abstract}

Reikšminiai žodžiai: urbanistikos paveldas, centrinè dalis, senamiestis, istorinis branduolys, centrinès dalies detalusis planas, bendrasis planas.

\section{Ivadas}

Lietuvos didžiųjų miestų paveldo apsaugos ir urbanistinio planavimo sovietinių metų praktikoje teisiškai saugomi tik senamiesčiai, t. y. tos senosios miesto dalys, kurios susikloste viduramžiais tarp miestų gynybinių sienų ar kitų aiškiai identifikuotų istorinio branduolio ribų. Tos teritorijos sovietiniais metais buvo paskelbtos urbanistiniais paminklais ${ }^{1}$. Tai buvo fakto konstatavimo etapas, daug vèliau prasidejjo diskusijos dèl urbanistinių paminklų apsauginių zonų, urbanistikos paminklo sampratos, buvo identifikuojamas sovietinių metų palikimo santykis su iki $1940 \mathrm{~m}$. susiklosčiusia aplinka (Bučas 1995: 169). Žlugus Sovietų Sąungai ir komunistinei Rytų Europai, pra-

\footnotetext{
1949 m. ị Lietuvos architektūros paminklų sąrašą buvo ịtraukt Vilniaus, Kauno, Kèdainiu ir Klaipèdos senamiesčiai. 1954 m. parengtas Vilniaus, o iki 1964 m. - Kauno, Kèdainių ir Klaipèdos senamiesčiu „rekonstrukcijos“ projektai.
}

sidejo dabarties interesus atitinkantys istorinès praeities rekonstrukcijos procesai, kurie sukūrè naujas problemas - koks paveldas ir kieno paveldas (Čepaitienè 2009: 50-77).

1969 m. sausio 27 d. paskelbtas Lietuvos urbanistinių paminklų sąrašas². Taigi 62 miestai ir miesteliai buvo paskelbti vietos reikšmès urbanistikos paminklais, iš jų Telšiams ir Ukmergei 1989 m. kovo $10 \mathrm{~d}$. LSSR Ministrų tarybos nutarimu Nr. 53 buvo suteiktas respublikinės reikšmès senamiesčio rangas. Trakai kartu su kitais objektais (t. y. 61 objektu) 1969 m. sausio $27 \mathrm{~d}$. gavo vietinès reikšmès urbanistikos paminklo statusą, tačiau netrukus buvo priskirti prie respublikinès reikšmès senamiesčių. Šilutė 1988 m. gruodžio

\footnotetext{
2 LTSR kultūros ministro ir LTSR Ministrų tarybos valstybinio statybos reikalų komiteto pirmininko ịsakymas Nr. 37/16 (1969 m. sausio 27 d.).
} 
22 d. LSSR Kultūros ministerijos kolegijos nutarimu Nr. 222 papildomai paskelbta vietinès reikšmès urbanistikos paminklu (Lietuvos urbanistikos... 2005: 6-7). İdomi detalè - paminklų sąraše nèra Šiaulių ir Panevėžio miestų. Nèra šių miestų ir $1980 \mathrm{~m}$. patikslintame Lietuvos urbanistinių paminklų sąraše ${ }^{3}$.

Nuo 1979 m. Lietuvos statybos ir architektūros mokslinio tyrimo instituto (LSAMTI) Urbanistikos sektoriuje buvo pradèti kryptingi istorinių miestų tyrimo ir architektūrinio formavimo principinių siūlymų rengimo perspektyvinio modeliavimo darbai (Lietuvos urbanistikos... 2005). 1979-1985 m. metodinès rekomendacijos (darbo vadovas - LSAMTI urbanistikos sektoriaus vadovas A. Miškinis) senajai ir naujajai architektūrai integruoti projektuojant Lietuvos TSR istorinius miestus yra parengtos ir Šiaulių miesto istorinei daliai, nors Šiauliai buvo traktuojami kaip miestas, kuriame nèra iš anksto fiksuotų istorinio branduolio ar centro ribų. Šis faktas paaiškinamas, nes „totalinio“ vertybių registro kontekste dominavo samprata, kad vertingi yra tik paminklo statusą turintys objektai, o paminklosaugos (paveldosaugos) viešasis administravimas traktuojamas kaip pagrindinis paveldo apsaugos mechanizmas.

Iš kitos pusès, juridinio statuso suabsoliutinimas yra kraštutinumas. Pvz., 1993 m. Paminklotvarkos departamentas (dabar KPD) ir PRPI specialistų kolektyvas parengè Vilniaus miesto centrinès dalies paminklinių teritorijų planą (M1:5000), kuriame nurodyti urbanistikos paminklai (vietinès ir respublikinès reikšmès) ir architektūros kompleksai, turintys paminklo statusą. Prof. J. Bučas teigè, kad minètame darbe neteisingai formuluojama pati urbanistikos paminklo samprata, nes urbanistikos paminklo sampratą reikia formuluoti ne iš apsauginių, bet iš vertès pozicijų. Tam tikros vertes urbanistiniam kompleksui vien tik paminklo statuso nepakanka, nes apsaugos objektu gali būti ir žemesnio rango vertybès (Bučas 1995: 169). Tokia traktuotè leidžia atidžiau pažvelgti ị Šiaulių miesto centrinę dalį, kurios erdvinès struktūros savitumai yra mažai nagrinèti, neturi jokios legitimacijos, todèl nèra civilizuotos plètros garantas ${ }^{4}$.

\footnotetext{
3 LTSR kultūros ministro ir LTSR Ministrụ tarybos valstybinio statybos reikalų komiteto pirmininko ịsakymas Nr. 41/319 (1980 m. vasario 4 d.).

4 Visiškai kitais principais 1993-1995 m. atlikti Kauno ir Klaipèdos urbanistikos paveldo tyrimai, kurių tikslas - nustatyti saugotinas paveldo teritorijas kaip paminklosaugos prioritetines zonas iki $1940 \mathrm{~m}$. apstatytose miestų žemèse ir pateikti siūlymus teisiniam ju registravimui bei išsaugojimui. Tyrimu autoriai J. Bučas, A. Miškinis, konsultantas - J. Tatoris.
}

Akivaizdu, kad savo istoriją šimtmečiais skaičiuojantis Šiaulių miestas neturi aiškaus istorinio centro, senamiesčio. Silpnas bendruomenès kolektyvinès atminties „kultūrinis sluoksnis“ lemia, kad ịvairiuose mentaliniuose lygmenyse aktyviai propaguojamas proletariškas naratyvas „Šiauliai - pramonès ir darbininkų miestas", kuris iš esmès sumenkina bendrą kultūrinę tradiciją ${ }^{5}$ (Puronas 2009). Todèl pagrindinis straipsnio tikslas - ịvardinti ir metodiškai tiksliai suformuluoti Šiaulių miesto centrinès dalies ir istorinio centro sampratą, apibrěžti konkrečias šių teritorijų ribas, nes be šito sunkiai îsivaizduojama civilizuota urbanistinè pletra.

\section{Šiaulių miesto centrinès dalies architektūrinè urbanistinė koncepcija (2010 m.)}

2010 m. parengta Šiaulių miesto centrinès dalies architektūrinè urbanistinè koncepcija, kuri yra sudètinè Šiaulių miesto centrinès dalies detaliojo plano (DP) parengimo dalis ${ }^{6}$. Pagal DP užduotị planuojamos teritorijos plotas apie 686 ha, iš jų detalizuojama M1:500 apie 200 ha, o likusioji dalis rengiama schemos lygmenyje M1:2000. Nagrinèjamai teritorijai nurodomi skirtingi masteliai, tai rodo, kad centrinè dalis yra sudetingas urbanistinès struktūros atvejis.

Šiaulių miesto savivaldybès teritorijos bendrojo plano sprendiniuose $\mathrm{e}^{7}$ pateikta miesto centro suplanavimo schema M1:5000, kurioje nurodyti rekomenduojami užstatyto tankumo, intensyvumo, aukštingumo reglamentai, teritorijų naudojimo būdai ir pobūdžiai. Formaliai to pakanka viešojo administravimo sektoriui, bet iš tikrųjų yra visiškai neaiškūs užstatymo principai. Statistinių rodiklių visuma negarantuoja kokybiškos miesto erdvinès struktūros.

Šiaulių miesto centro suplanavimo schemoje M1:5000 yra nuoroda ị Šiaulių miesto senosios dalies aukštingumo specialųji planą. Kadangi šiuo metu tokio aukštingumo specialiojo plano nèra, DP koncepcijoje tenka spręsti ne tik utilitarius uždavinius, nurodytus užduotyje (sklypų formavimas, gatvių raudonųjų linijų tikslinimas, teritorijų visuomenès poreikiams rezerva-

\footnotetext{
5 Pvz., V. Purono knygoje „Saulès miesto veidas“ (2009) rašoma: „Šiauliai - pramonés miestas. Ta garbę gavome užgimę ir jai neleisime pražūti. Ereliais praskriskime virš Šiaulių istorijos tam, kad dar karta isitikintume pramonininko geležinio kumščio jega. Visos epochos, visi istoriniai Šiauliu renesansai buvo mūsu. raumenų ir galimybių kūriniai“.

6 DP rengejjas - UAB „Urbanistika“, projekto vadovas - A. Kažienè.

7 Šiaulių miesto bendrasis planas. 2009. Teritorijų planavimo dokumentų registro Nr. 006292001569.
} 
vimas ir t. t.), bet ir uždavinius, kurie yra susiję su miesto vizualiniu identitetu, erdviniu karkasu, nominaliu erdvių sistema ir pan. Todèl DP koncepcijoje atliekama Šiaulių miesto centrinès dalies erdvinio kompozicinio karkaso analizè ir pateikiama erdvinès struktūros vystymo idèja. Tai reiškia, kad DP koncepcija nèra tik formalus juridinis aktas, t. y. procedūra nèra pagrindinis kokybès kriterijus. Reikalinga erdvinès struktūros koncepcija. Kadangi nèra reglamentuota, kas yra "koncepcija“ ir kokie jai taikomi reikalavimai, svarbu tiksliai apibrèžti DP koncepcijos sampratą, nes tai susiję su urbanistikos (erdvinių struktūrų konstravimas) ir planavimo (procedūrinis veiksmų ir pasekmių planavimas) sampratų skirtumais. DP užduotyje nurodyta, kad senamiesčio teritorijoje sprendinius reikia pateikti M1:500 masteliu. Tai reiškia, kad koncepcija suprantama kaip meninis, profesinis teiginys.

Šiaulių miesto centrinès dalies koncepcija grindžiama principu, kad urbanistinè struktūra yra stabiliausias elementas, kurị keičiant kinta miesto identitetas, erdvinè struktūra ir pan. Tokiu atveju reikia rengti naujus urbanistinès plètros dokumentus. Susisiekimo ir inžinerinè infrastruktūra bei bendro naudojimo teritorijų ir želdynų sistema taip pat laikoma prioritetiniais elementais. Todèl miesto centrinès dalies urbanistinès struktūros elementų funkcinè integracija skirstoma $\mathfrak{i}$ siektiną, ribotiną ir netikslingą.

\section{Šiaulių miesto centrinès dalies samprata}

Šiaulių miesto centrinè dalis ịvairiai traktuojama. Norint tuo įsitikinti tereikia palyginti $1977 \mathrm{~m}$. Šiaulių miesto centrinès dalies detaliojo plano projektą (arch. E. Vilčinskas) ${ }^{8}, 1985 \mathrm{~m}$. Šiaulių miesto centrinès dalies detaliojo plano projektą (arch. A. Vyšniūnas) ${ }^{9}$ ir naujai rengiamo Šiaulių miesto centrinès dalies detaliojo plano užduotyje nurodytas planuojamos teritorijos ribas (1 pav.).

Su Šiaulių miesto centro (arba centrinės dalies) ribų identifikavimo problema susidūrè ir prof. A. Miškinis, sovietiniais metais rengdamas metodines rekomendacijas senajai ir naujajai architektūrai integruoti Lietuvos istoriniuose miestuose. Prof. A. Miškinio

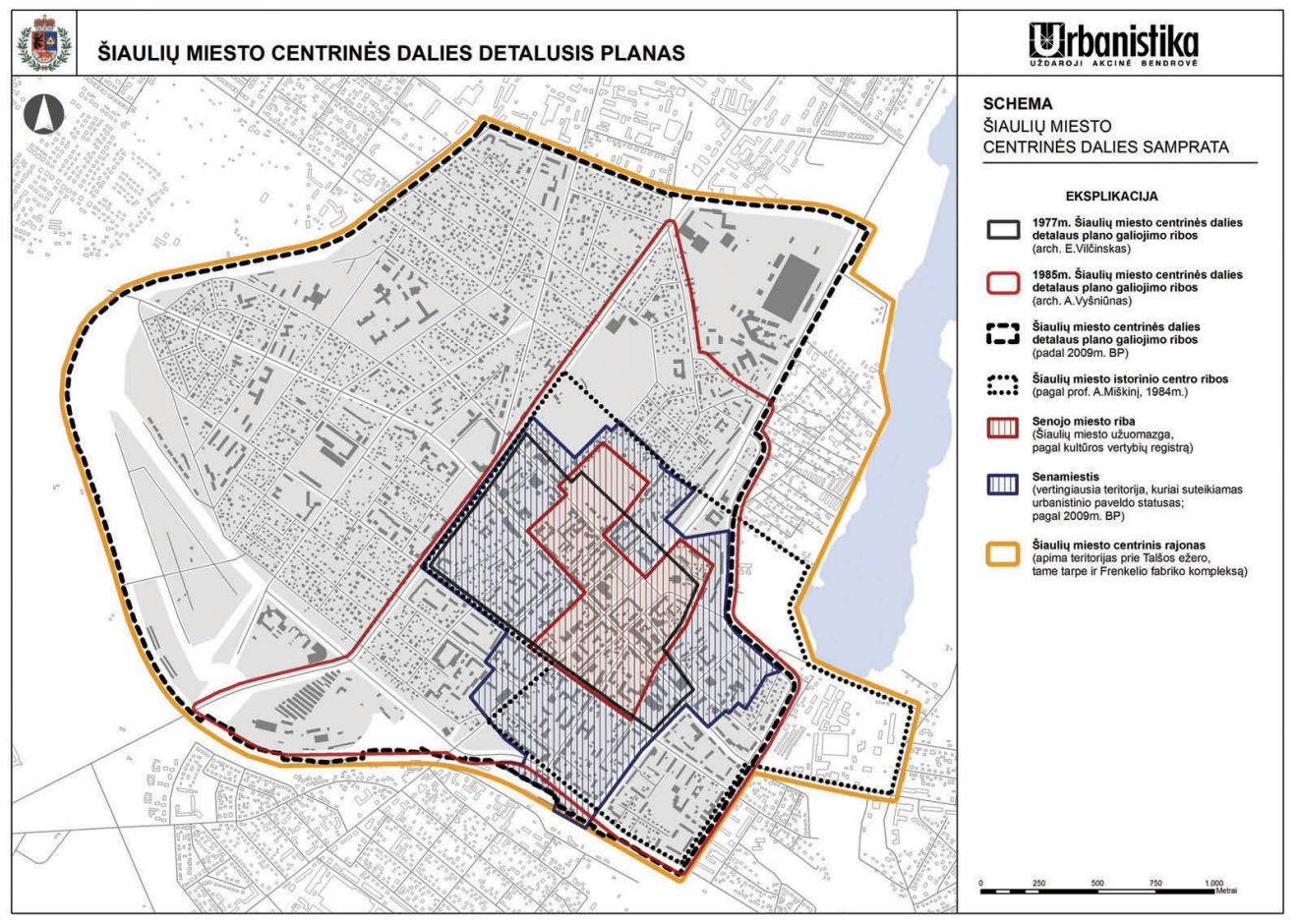

1 pav. Šiaulių miesto centrinès dalies sampratos schema

Fig. 1. The conceptional layout of the central part of Šiauliai

81977 m. Šiaulių miesto centrinès dalies detaliojo plano projektas (arch. E. Vilčinskas). MSPI Šiaulių skyrius.

91985 m. Šiaulių miesto centrinès dalies detaliojo plano projektas (arch. A. Vyšniūnas). MSPI Šiaulių skyrius. 
nuomone, centrui priklauso ir Frenkelio fabriko kompleksas (Lietuvos urbanistikos paveldas 2005: 157). Be to, 2009 m. patvirtintame Šiaulių miesto bendrajame plane kalbama apie Šiaulių miesto senamiestį. Tai yra istoriškai susiklosčiusi teritorijos dalis, kurios buvimo faktas identifikuoja iš esmès naują Šiaulių miesto urbanistinès struktūros kokybės etapą. Senamiestis yra Šiaulių miesto centro dalis. Todèl reikia aiškiai skirti terminus - istorinis centras (Šiaulių miesto užuomazga, apima senamiestị ir istorinius priemiesčius), senamiestis (vertingiausia miesto urbanistinès struktūros dalis su pagrindine Prisikèlimo aikšte, t. y. teritorija, kuriai suteikiamas urbanistinio paveldo statusas), Šiaulių miesto centrinè dalis (teritorija, kurią apibrèžia geležinkelis ir B kategorijos Ežero gatvè, t. y. planuojama teritorija), Šiauliu miesto centrinis rajonas (apima teritorijas prie Talšos ežero, taip pat ir Frenkelio fabriko kompleksą).

Naujai rengiamo Šiaulių miesto centrinès dalies detaliojo plano užduotyje nurody tos planuojamos teritorijos ribos nustatytos, remiantis galiojančiu Šiaulių miesto bendruoju planu ${ }^{10}$.

\section{Bendra Šiaulių miesto centrinès dalies charakteristika. Problemos aktualumas}

Šiaulių miesto centrinès dalies morfotipų ir dominuojančių funkcijų analizè parodé, kad didžioji planuojamos teritorijos dalis (rytine dalis, t. y. teritorija tarp geležinkelio ir Žemaitès gatvès) neturi centrui būdingų funkcijų (mišrios paskirties, kultūrinių ir kt. funkcijų), todèl šios teritorijos priskyrimas prie centro yra sąlyginis. Tai patvirtina ir užduotyje pateiktas reikalavimas šios dalies DP sprendinius rengti schemos lygmeniu M1:2000 masteliu, nors senamiestyje reikalaujamas mastelis M1:500. Be to, minètoje Šiaulių miesto centrineje dalyje yra labai daug individualaus sodybinio tipo užstatymo, kuris aiškiai yra neadekvatus teritorijos statusui miesto urbanistinèje struktūroje. Vakarų Europoje naudojamas miesto teritorijos įsisavinimo rodiklis yra būstų ${ }^{11}$ kiekis hektare. Šiauliuose šis rodiklis labai žemas - mažiau nei 20 būstų hektare, nors V. Europoje šis rodiklis siekia 100 būstų hektare ir daugiau.

Intensyvūs urbanizaciniai procesai, ypač Lietuvos miestų centrinėse dalyse, vyksta sparčiai, bet ne visais

\footnotetext{
10 Šiaulių miesto bendrasis planas. 2009. UAB „Urbanistika“.

${ }^{11}$ Būstas suprantamas kaip butas arba individualus gyvenamas namas.
}

atvejais yra aišku, kokios tolesnio urbanizavimo maksimalios leistinos ribos, koks užstatymo morfotipas ir kokie užstatymo rodikliai. Pagrindinè problemos atsiradimo priežastis - žemės nuosavybès santykių kaita, naujų sklypų (ypač labai didelių, viršijančių tradicinị sklypų modulį) formavimas ir (ar) atsiradimas žaliosiose zonose bei istoriškai susiklosčiusiose struktūrose. Tokia problema nèra būdinga tik Šiauliams, tai yra aktualu ir kitiems Lietuvos miestams.

Žemès nuosavybès „modulinis tinklas" ${ }^{\text {"12 }}$ kinta todèl, kad sujungiami keli sklypai arba keičiasi sklypų sistema konversinèse teritorijose. Šito pasekmè - dominuojančio morfotipo kitimas iš esmès. Taip pat akivaizdus naujų žemès savininkų noras intensyvinti užstatymą.

Urbanizavimo laipsnio nustatymas tèra pasekminè problema. Ją spręsti padètų aiškus žaliųjų plotų, viešųjų erdvių sistemos ir urbanistinio paveldo identifikavimas. Šiauliuose ši problema yra ypač aktuali miesto centriniame rajone, senamiestyje ir prie Vilniaus gatvès, kuri yra svarbus elementas miesto urbanistinèje struktūroje. Tai liečia ir pagrindinę Šiaulių miesto aikštę.

\section{$1985 \mathrm{~m}$. Šiaulių miesto centrinès dalies detaliojo plano charakteristika}

$1985 \mathrm{~m}$. Šiaulių miesto centrinès dalies detalusis planas ${ }^{13}$ (MSPI Šiaulių skyrius, architektas Algis Vyšniūnas) buvo rengiamas sovietiniais metais, kai nebuvo žemès nuosavybės rinkos, buvo labai žema statybos kultūra, skurdi materialinè bazè, tai lèmé sovietinių laikų tipinių projektų mechanišką taikymą istorineje aplinkoje. Direktyvinio planavimo sąlygomis buvo ypač sudètinga civilizuotai spręsti urbanistinio paveldo problemas. Tai lèmé ne tik paveldosaugos tradicijų ir institucijų Šiaulių mieste nebuvimas, metodologiškai silpnai motyvuota paveldo samprata, bet ir vidinio poreikio nebuvimas saugoti istorinio miesto ypatumus ${ }^{14}$.

\footnotetext{
12 Žemės nuosavybės modulinis tinklas reiškia žemès sklypų dydžių, vietos mieste ir nuosavybės santykių sisteminę priklausomybę.

${ }^{13}$ LTSR VSRK MSPI Šiaulių skyrius. 1985. Kompleksas 5299.

${ }^{14}$ Vidinio poreikio nebuvimas saugoti istorinio Šiauliu miesto ypatumus lengvai irodomas, palyginus 70 -uju m. Klaipedos ir Šiaulių miestų valdžios veiksmus. Tuo metu, kai Klaipėdoje buvo ikurtas Paminklu konservavimo instituto skyrius, inventorizuojamas senamiestis, telkiami kadrai, kuriama paveldosaugos sistema ir t. t., Šiauliuose intensyviai spalvojami fasadai. Gyvenimas parodè, kad tai tèra laikinos kosmetinès priemonès, kurios duoda tam tikrą lokalų rezultatą, bet iš tikrųjų nepadeda spręsti fundamentinių miesto formavimo uždavinių.
} 
Pagrindinis $1985 \mathrm{~m}$. Šiaulių miesto centrinès dalies DP tikslas buvo sumažinti sovietinių laikų urbanizacijos pasekmes, reabilituoti tradicinès erdvès istoriškai susiklosčiusioje miesto dalyje sampratą. Praejjus daugiau kaip ketvirčiui amžiaus, galima daryti kai kurias išvadas. Atlikta įvykusių pasikeitimų (nauji žemès nuosavybės santykiai, naujas užstatymas ir pan.) analizè leidžia teigti, kad iš esmès prisilaikyta pagrindinių 1985 m. DP teiginių - išlaikomos istoriškai susiklosčiusios gatvių raudonosios ir užstatymo linijos, respektuojamas kvartalinis morfotipas, išlaikomas architektūrinis mastelis, nauji objektai neviršija foninio kvartalo aukštingumo, centre neatsirado aukštybinių pastatų ir pan.

Bet kai kas pasikeite iš esmès. Po $1990 \mathrm{~m}$. miesto centre atsirado konversinių teritorijų problema, tai buvo neaktualu $1985 \mathrm{~m}$. Sovietinių pramonès įmonių miesto centrinèje dalyje buvo nemažai, jos užèmè dideles teritorijas, pastatų architektūra prasta. Šias teritorijas galima traktuoti kaip didžiulius teritorinius rezervus. Šiaulių miesto urbanistinių struktūrų kitimo schemą (1985 m.) palyginus su dabartine situacija, matosi kad šios teritorijos yra pačios problematiškiausios, todèl šių teritorijų urbanistinè plètra turi būti planuojama ypač atidžiai. Neišspręsta liko Prisikèlimo aikštès problema, neaiškūs aikštès matmenys.

$1985 \mathrm{~m}$. detaliajame plane buvo atliktas centrines dalies pastatų architektūros vertinimas pagal tam tikrą sukurtą kriterijų sistemą - kompozicinè mintis ir jos išraiškingumas; stiliaus ar srovès atstovas; atskiru elementų santykis tarpusavyje ir su visuma; pastato santykis su aplinka; pastato dydžio ir jo elementų santykis su žmogumi; spalva; techninè būklè ir t. t. Reikia konstatuoti, kad ši metodika nebuvo tobulinama, todèl daug kur pastatai rekonstruojami be aiškesnių principų, nors esminių urbanistinių klaidų lyg ir nèra. Kadangi Šiaulių BP (2009 m.) kalbama apie senamiesti, todèl centrinès dalies pastatų architektūros vertinimas turètų būti atliekamas pagal specialųji planą ${ }^{15}$.

Naujų funkcijų, nebūdingų senamiesčiui, atsiradimas taip pat yra reali problema. Kalbama apie prekybinius centrus, kurie užima dideles teritorijas, pritraukia daug automobilių ir t. t. Iš kitos pusès, kultūrinès paskirties objektų (koncertų salès, muziejai, meno centrai

\footnotetext{
15 Tokio darbo poreikis akivaizdus, kitaip - svarbių unikalių objektu likimas sunkiai prognozuojamas. Pvz., taip atsitiko su architekto A. Ratniko autobusų stoties pastatu, kuris buvo sunaikintas, o jo vietoje atsirado prekybos ir pramogų centras „Saulès miestas".
}

ir t. t.) plètra miesto centre iš esmès nevyksta, o kultūrinių funkcijų dispersija yra apskritai nenagrinèta. Kalbos apie „Kultūros fabriką" Ch. Frenkelio pramoniniame komplekse Vilniaus gatveje esmès nekeičia.

1985 m. detaliajame plane buvo atlikta Šiaulių miesto urbanistinès struktūros istorinès raidos analizè, remiantis istoriografine medžiaga (Senieji Šiauliai atvirukuose 2006). Analizè nepretenduoja ị išsamią istorinę studiją, bet yra tikslinga parodyti Šiaulių miesto urbanistinès struktūros ir architektūrinių objektų bei ansamblių ypatumus. Senų nuotraukų ir miesto planų analizè parodė, kad Šiauliuose dar yra ženklų, kurie leidžia atpažinti senąją struktūrą. Šios struktūros „reabilitacija" buvo pirmaeilis DP uždavinys.

\section{Šiaulių miesto planinès struktūros ir pagrindinių jos elementų (Vilniaus gatvès ir Prisikèlimo aikštės) istorinès raidos analizè}

Reikšmingą informacinių šaltinių dalị sudarè įvairių laikotarpių urbanistikos ir architektūros mokslininkų tyrimai (Lietuvos architektūros istorija 1994; Šešelgis 1996; Neniškis 2002), urbanistinès plètros Šiaulių miesto istorineje aplinkoje galimybių studijos $^{16,17}$, straipsniai profesineje spaudoje (Archiforma 2002) ir t. t.

Didžiuosiuose miestuose teisiškai saugomos senosios miestų dalys, kurios buvo paskelbtos urbanistikos paminklais. Paprastai tokio tipo teritorijos užima nedidelę miesto dali. Taip yra ir su Šiauliais, tik čia nera įvardintos tos saugomos teritorijos, nors miesto istorija siekia beveik $800 \mathrm{~m}$. Todèl svarbu atrinkti ir teisiškai užregistruoti urbanistikos paveldo saugotinas teritorijas. Būtina prisilaikyti tam tikrų pagrindinių urbanistikos paveldo saugotinų teritorijų identifikavimo metodinių principų. Saugotinas urbanistikos paveldas - teritorijos, kurios turi istorinę, kultūrinę vertę, kartu atspindi miesto formavimosi etapus. Pagrindiniai vertès nustatymo kriterijai - istorinis informatyvumas ir urbanistinès struktūros brandumas.

Reikšmingą informacinių šaltinių dalị sudarè įvairių laikotarpių urbanistikos ir architektūros moksli-

\footnotetext{
${ }^{16}$ Sklypo Ežerog. 22 ir 20 Šiauliuose galimybiu studija užstatymo principų ir aukštingumo aspektu. 2007. VGTU Urbanistikos katedra.

${ }^{17}$ Teritorijos tarp Žemaitès g., Dobilo g. ir centrinio parko Šiauliuose galimybių studija aukštingumo aspektu. 2007. VGTU Urbanistikos katedra.
} 
ninkų tyrimai (Lietuvos architektūros... 1994; Šešelgis 1996; Neniškis 2002) urbanistinès plètros Šiaulių miesto istorineje aplinkoje galimybių studijos ${ }^{18}, 19$, straipsniai profesineje spaudoje (Archiforma 2002) ir t. t.

Istorinis užstatymas susiklostè žemès nuosavybès modulinio tinklo pagrindu. Sovietiniais metais šios logikos buvo nepaisoma, todèl tai tapo pagrindine urbanistinių struktūrų deformacijos priežastimi. Tam tikrais statybos periodais būdavo skirtingas užstatymo tankumas, o tai reiškia, kad kiekvieną užstatymo morfotipą atitinka tam tikras užstatymo tankumas ir vidutinis aukštingumas. Tankumo ribą įveikti įmanoma tik suardant planinę bei erdvinę struktūrą. Tai reiškia, kad vienas morfotipas keičia kitą. Istorinio užstatymo morfotipus būtina saugoti ir tobulinti, atsižvelgiant $i$ erdvinius désningumus. Vertingiausi fragmentai ten, kur yra kvartalinis posesinis užstatymo morfotipas. Urbanistinio formavimosi ypatybès nustatomos analizuojant istorinius planus, kartu lyginant juos su dabartine situacija. Ivertinamas planavimo laikas, teritorijos apstatymo laikas ir mastas, teritorijos prijungimo prie miesto žemių metai. Šiaulių miesto atveju senieji istoriniai planai kiek daugiau informacijos suteikia tik apie centrinę dali. Atlikus tokio tipo analizę akivaizdu, kad senosios miesto dalies urbanistinè struktūra yra gana stipriai deformuota, bet dar neviršijo kritinès ribos, po kurios prasideda nebegrižžtami procesai. Urbanistinių deformacijų ir anomalijų analizè rodo, kad vienintelis būdas apsaugoti istoriškai susiklosčiusią urbanistinę struktūrą nuo visiško sunaikinimo - laikytis pagrindinių paminklotvarkinių principų (išlaikyti posesinę struktūrą, posesijų apstatymo pobūdị, esminius miesto identiteto aspektus ir t. t.).

Iš istoriografinès medžiagos matosi, kad Šiaulių miesto planinès struktūros pagrindiniai strateginiai elementai yra šie: bažnyčia; dvaras; ašis tarp bažnyčios ir dvaro su pagrindine miesto aikšte; pagrindinių gatvių, kertančių visą miestą (Vilniaus, Tilžès), sankryža; fonini užstatymą formuojantys kvartalai. Visi išvardinti strateginiai struktūros elementai išsidestę teritorijoje, kurią riboja Žemaitės g., Ežero g. ir geležinkelis. Tai yra teritorija, kurioje įmanoma atsekti struktūros formavimosi periodus, ypatybes. Tai yra vadinamasis istorinis centras. Beveik visuose senuosiuose miesto planuose buvo respektuojama pagrindinè aikštè. Labai

\footnotetext{
${ }^{18}$ Sklypo Ežero g. 22 ir 20 Šiauliuose galimybiu studija užstatymo principų ir aukštingumo aspektu. 2007. VGTU Urbanistikos katedra.

19 Teritorijos tarp Žemaitess g., Dobilo g. ir centrinio parko Šiauliuose galimybiu studija aukštingumo aspektu. 2007. VGTU Urbanistikos katedra.
}

svarbu šiandieninès struktūros autentiškumas ir fizinè būklè. Pagrindinis kriterijus, nustatant struktūros autentiškumą - deformacijų pobūdis ir mastas.

Senųjų Šiaulių miesto planų analizè parodè, kad dabartinès Prisikèlimo aikštès ribos ir skveras kitoje Tilžès g. pusèje susiformavo XIX a. viduryje. Tuo metu aikštès išklotinę šiaurineje dalyje formavo prekybiniai paviljonai. Šv. Petro ir Povilo bažnyčia visada buvo pagrindinè aikštès erdvès ir viso miesto dominantė. Sovietiniais metais aikštess kompozicija buvo konstruojama pagrindinį dèmesị skiriant stalinistinès architektūros pastatui (dabartinès Šiaulių kolegijos pastatas) su paminklu sovietiniam kareiviui prieš ji. Tuo pačiu metu iš skvero cerkvė perkelta prie senųjų kapinių. Atlikta istoriografinès medžiagos analizè parodé, kad Prisikèlimo aikštės vertè yra sudètinè. Verčių komplekso struktūra: a) vertingi objektai, architektūriniai urbanistiniai kompleksai; b) nominalių erdvių sistema apie objektus ir architektūrinius urbanistinius kompleksus; c) vertingi (charakteringi) vaizdai, užfiksuoti fotografijose, piešiniuose ir t. t.; d) svarbių miesto dalių istorinès ribos (senamiesčio, aikštes, dvaro ir t. t.).

\section{Šiaulių miesto bendrųjų (generalinių) planų apžvalga}

Pokario metais iki pat nepriklausomybès atkūrimo buvo parengti trys Šiaulių miesto generaliniai planai $^{20}-1959,1963$ ir 1980 m. Šiuos generalinius planus (toliau Bendrieji planai BP) galima lyginti ịvairiais aspektais, bet pagrindinis skirtumas - skirtingos miesto fizinès plètros strateginès koncepcijos. Kartu reikia suvokti, kad šie planai buvo parengti visiškai kitoje ekonomineje bei politineje aplinkoje, planai rengiami naudojant netobulus duomenų rinkimo ir apdorojimo metodus, planų grafinis tikslumas nepakankamas ir t. t.

2002 m. St „Šiaulių planas“ atliko Šiaulių miesto bendrojo plano priešprojektinius darbus (tyrimus), kurių rezultatai buvo pristatyti specialioje konferencijoje. Likvidavus SI „Šiaulių planas“, BP rengimas perduotas UAB „Urbanistika“ (Vilnius) ${ }^{21}$.

Sovietinių laikų planai lengvai skaitomi, aiškiai suvokiama pagrindinè idejja. Urbanizuotose teritorijose nurodomas skirtingas užstatymo aukštingumas (pvz., 1-2;3-4 aukštų namai, individualūs gyv. namai), todèl galima suvokti pagrindinę erdvinę idèją. Tokio aiškumo netenka dabartiniai BP (parengti pagal $1995 \mathrm{~m}$.

\footnotetext{
${ }^{20} \mathrm{UAB}$ „Urbanistika“ archyvas.

${ }^{21} 2009 \mathrm{~m}$. patvirtintas UAB „Urbanistika“ (Vilnius) parengtas Šiaulių miesto bendrasis planas. Projekto vadovè - A. Kažienè. BP koncepcijos autoriai - A. Vyšniūnas, G. Ratkutè.
} 
Teritorijų planavimo įstatymą), kuriuose nurodoma žemès paskirtis ir naudojimo būdas bei pobūdžiai. Kitas dalykas, kai kalbama apie profesinius sprendinius. Nagrinèjami Šiaulių miesto BP labai skirtingi. Ypač tai aktualu, kalbant apie istorinị centrą, nes tai yra susiję su bendra tuo metu egzistavusia paveldo samprata.

Vilniaus gatvè visais laikais buvo viena iš pagrindinių miesto gatvių, einanti per visą miestą. Taip jau susiklostė, kad Vilniaus gatvę galima skirstyti ị dvi dalis. Rytinė dalis (nuo Ežero g. iki Žemaitès g.). Ši dalis eina per senamiestị ir pasižymi gana aiškiu kvartaliniu užstatymo morfotipu. Erdvinis karkasas yra beveik suformuotas, belieka tobulinti tūrinę-erdvinę kompoziciją. Dominuojantis erdvès tipas - gatvè.

Didžioji Vilniaus gatvès dalis sovietiniais metais paversta pessčiųjų alëja. Kai kur (pvz., prie Universalinès parduotuvės viduryje Vilniaus gatvės važiuojamosios dalies) pasodinti medžiai, kurie išaugo ir dabar tai galima traktuoti kaip skverą. Dèl sovietiniais metais įrengtos pèsčiųjų alèjos Šiaulių istoriniame centre (senamiestyje) yra silpnas gatvių tinklas, todèl didelių nauju objektų statyba ten nerekomenduojama. Užstatymas vakarinès dalies (nuo Žemaitės g. iki Kuršènų pervažos) ruože yra neadekvatus gatvès statusui ir vietai miesto urbanistineje struktūroje. Pagrindinis šios teritorijos ypatumas - dominuoja sodybinio užstatymo morfotipas. Tai reiškia, kad yra labai žemas urbanizacinis laipsnis, todèl neišvystyta socialinè ir paslaugu infrastruktūra.

Išanalizavus sovietinių laikų Šiaulių miesto bendruosius planus, galima daryti išvadą, kad Vilniaus gatvè visą laiką buvo aktyvių urbanizacinių veiksmų zonoje. Todèl tolesnis nagrinejamos teritorijos užstatymo intensyvinimas yra natūrali vykstančiu procesų tąsa. Visuose bendruosiuose planuose didelis demesys skiriamas architektūrinei urbanistinei nagrinejjamos teritorijos koncepcijai (siūloma formuoti aikštes ir pan.). Bendruosiuose planuose akivaizdi naujojo centro kaip svarbaus struktūrinio elemento miesto urbanistinejje struktūroje galimybè. Aiškiai apibrežtas Šiaulių miesto centrinis rajonas, nors senamiestis neidentifikuotas.

\section{Šiaulių miesto centrinès dalies mokslinès studijos ir metodinès rekomendacijos}

1979-1985 m. Lietuvos statybos ir architektūros mokslinio tyrimo instituto (LSAMTI) Urbanistikos sektoriuje buvo vykdomi kryptingi istorinių miestų tyrimo ir architektūrinio formavimo principinių siūlymu rengimo perspektyvinio modeliavimo darbai (Lietuvos urbanistikos... 2005). Metodinès rekomendacijos senajai ir naujajai architektūrai integruoti parengtos ir Šiaulių miesto istorinei daliai.

Atlikus nagrinèjamos teritorijos esamos būklès tyrimų suvestines ir nustačius šios būklès ir projektinių duomenų sąveikos realias galimybes, aiškejja miesto istorinès dalies tolesnio formavimo koncepcija. Ji priklauso ne tik nuo esamų vertybių išsaugojimo, respektavimo ir išvystymo, bet ir nuo naujų vertybių sukūrimo programos. Tokiam miestui kaip Šiauliai, t. y. miestui be urbanistikos paminklo statuso, yra būtina padidinti centro (istorinio branduolio) funkcinę reikšmę ir vaidmenį mieste. Taip pat būtina taisyti urbanistines klaidas ar mažinti jų poveikị.

Nagrinejjamos teritorijos urbanistinio pertvarkymo ir statybos režimas nustatomas atsižvelgiant ị bendrą formavimo koncepciją, atskirų zonų (dalių) vertę ir būklę, išryškèjusią tiriant esamą būklę, ịvertinus ir toms dalims skirtą vaidmenị pagal miesto perspektyvinio vystymo duomenis. Paprastai atskirose nagrinejamos teritorijos dalyse pertvarkymo priemoniu požiūriu susidaro penki skirtingi statybos režimai ir tam tikras vienas dominuoja: a) apsauga. Urbanistinė struktūra iš esmès nekeistina, menkaverčiai pastatai gali būti griaunami; b) architektūrinè urbanistinè rekonstrukcija (minimali, optimali, radikali); c) funkcinè rekonstrukcija (konversija). Formuojant teritoriją, būtina laikytis istorinès statybos linijos, susiklosčiusio užstatymo pobūdžio, erdvių mastelio, bendro vaizdo reikšmès viso miesto vaizdų hierarchijoje (Lietuvos urbanistikos... 2005: 163).

2002 m. Šiauliuose vyko konferencija, kurioje buvo pristatyti Šiaulių miesto bendrojo plano priešprojektiniai darbai (tyrimai) ${ }^{22}$. Konferencijoje pranešimus skaitė VGTU Urbanistikos katedros vedèjas doc. A. Vyšniūnas (Vyšniūnas 2002) ir dr. E. Neniškis (Neniškis 2002), apibendrinęs savo daktaro disertacijos išvadas (Neniškis 2002). Viena pagrindinių priešprojektinių darbų (tyrimų) architektūrinès urbanistinès dalies išvadų - Šiauliuose būtina identifikuoti istorinị branduolį ir suteikti šiai teritorijai senamiesčio statusą. Ši nuostata buvo ịvertinta Šiaulių miesto bendrajame plane, kuris patvirtintas $2009 \mathrm{~m}$.

$2004 \mathrm{~m}$. ikurta VGTU Urbanistinès analizès mokslo laboratorija prie Urbanistikos katedros. Tai leido moksliniams tyrimams suteikti labiau taikomąji pobūdị. Atlikta daug urbanistinès plètros galimybių

\footnotetext{
${ }^{22}$ Priešprojektinių darbų (tyrimų) organizatorius SI „Šiaulių planas“. 2002.
} 


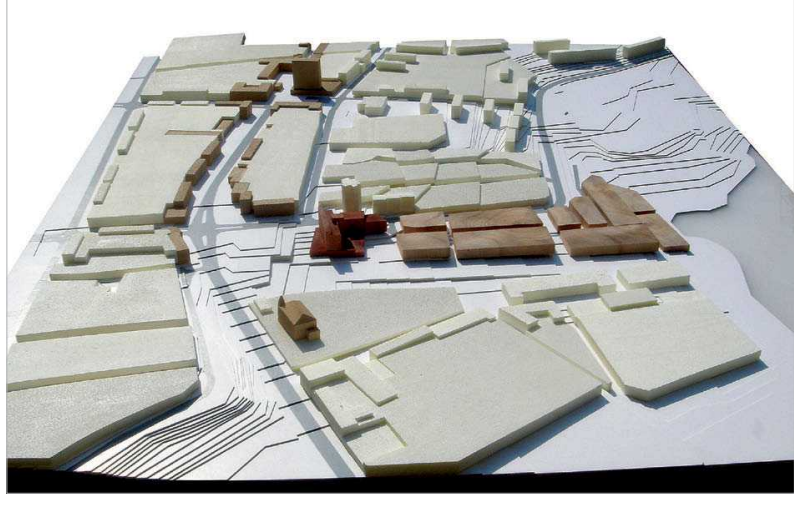

2 pav. Sklypo Ežero g. 22 ir 20 Šiauliuose galimybiu studija užstatymo principu ir aukštingumo aspektu. VGTU Urbanistinès analizès mokslo laboratorija, 2007. Darbo vadovas - prof. A. Vyšniūnas

Fig. 2. The potential study of the site on Ežeras street 22 and 20 in Šiauliai by the principle of constructional development and the aspect of altitude.

Analysis of Research Laboratory of Urban Design in Vilnius Gediminas Technical University, 2007. Head of the scientific research - Prof. A. Vyšniūnas

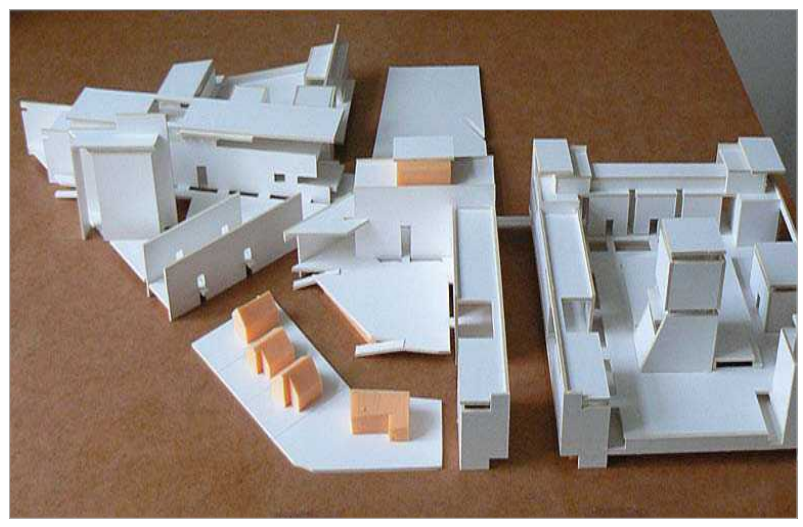

3 pav. Teritorijos tarp Žemaitės g., Dobilo g. ir centrinio parko Šiauliuose galimybių studija aukštingumo aspektu. VGTU Urbanistinès analizès mokslo laboratorija, 2007. Darbo vadovas - prof. A. Vyšniūnas

Fig. 3. The potential study of the territory between Žemaite and Dobilas streets and and the central park in Šiauliai by the aspect of altitude Analysis of Research Laboratory of Urban Design in Vilnius Gediminas Technical University, 2007. Head of the scientific research - Prof. A. Vyšniūnas

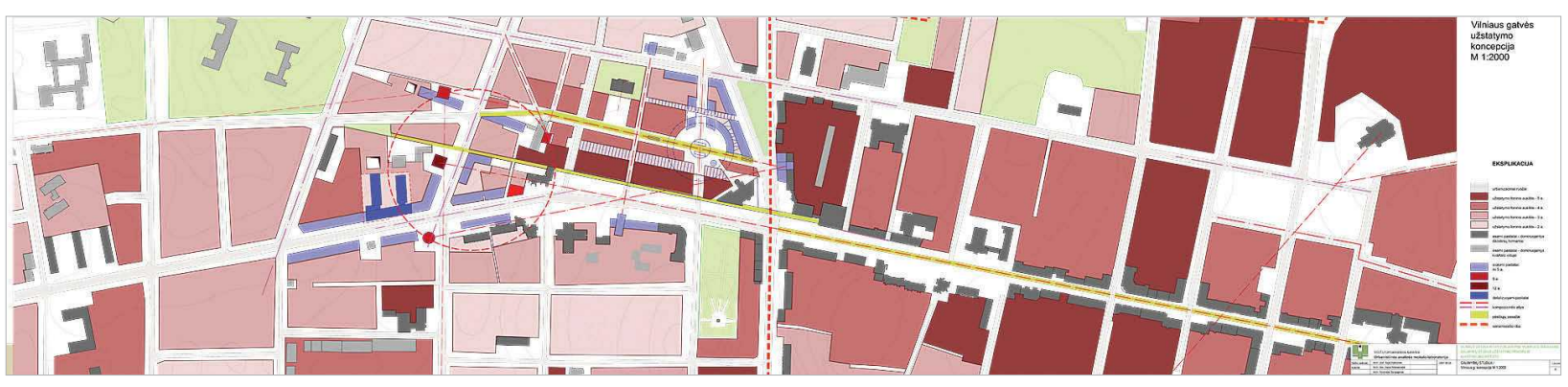

4 pav. Vilniaus g. ir teritorijos prie Vilniaus g. Šiauliuose galimybių studija užstatymo principų ir aukštingumo aspektu. VGTU Urbanistinès analizės mokslo laboratorija, 2007. Darbo vadovas - prof. A. Vyšniūnas

Fig. 4. The potential study of Vilnius street and its surroundings in Šiauliai by the principle of constructional development and the aspect of altitude. Analysis of Research Laboratory of Urban Design in Vilnius Gediminas Technical University, 2007. Head of the scientific research - Prof. A. Vyšniūnas

studijų ${ }^{23,24,25}$, kuriose pateiktos labai konkrečios rekomendacijos, padedančios sukonkretinti užstatymą reglamentuojančių rodiklių sistemą (2, 3, 4 pav.).

\footnotetext{
${ }^{23}$ Sklypo Ežero g. 22 ir 20 Šiauliuose galimybių studija užstatymo principų ir aukštingumo aspektu. 2007. VGTU Urbanistikos katedra.

${ }^{24}$ Teritorijos tarp Žemaitès g., Dobilo g. ir centrinio parko Šiauliuose galimybių studija aukštingumo aspektu. 2007. VGTU Urbanistikos katedra.

${ }^{25}$ Vilniaus gatvès ir teritorijos prie Vilniaus g. Šiauliuose galimybių studija užstatymo principų ir aukštingumo aspektu. 2007. VGTU Urbanistikos katedra.
}

Kitas svarbus momentas - minèti tyrimai apibrěžè hipotetinį urbanistinių argumentų lauką. Akivaizdu, kad norint tinkamai reglamentuoti prognozuojamą užstatymą reikia atitinkamai pateikti medžiagą, t. y. būtina tam tikro lygio urbanistinè argumentacija. Tam reikalingas projektuojamo komplekso ar objekto maketas (pageidautina, kad būtų kontekstas), būtina ịvertinti jo pasekmes miesto vizualiniam identitetui ir t.t. Todèl urbanistinès plètros galimybių studijų reikšmė ateityje tik didès.

Be to, Urbanistikos katedros mokslininkai parašè daug straipsnių apie Šiaulių miesto urbanistinę plètrą 
(Vyšniūnas 2000: 163-170; Butkus 2010, Vyšniūnas 2007a, 2007b). Visą šį teorinị ir praktinị ịdirbị siūloma panaudoti, rengiant Šiaulių miesto centrinès dalies detalụji planą.

\section{Šiaulių miesto centrinès dalies detalieji planai, projektiniai pasiūlymai, kūrybinès dirbtuvès, architektūriniai konkursai}

Užsakovas (Šiaulių mieto savivaldybė) DP rengèjams pateikè detaliųjų planų (apie 350), parengtų Šiaulių miesto centrinei daliai, sąrašą. Formalus reikalavimas - atsižvelgti $i$ jau ịvykusius procesus. Išnagrinejjus šiuos teritorijų planavimo dokumentus, galima daryti išvadą, kad ne visi Šiaulių miesto detalieji planai yra kompleksiški ir atitinka tokiems planams keliamus reikalavimus, t. y. kai kurie detalieji planai neturi reikiamos urbanistinès ir meninès argumentacijos.

Anksčiau parengtus detaliuosius planus reikia vertinti pagal tam tikrus kriterijus. Pagrindinis kriterijus - pateikiamos medžiagos išsamumas ir konkretumas. Tai nustatoma, konstatuojant ar: a) patvirtintas DP turi privalomas dalis ir tikslius reglamentus; b) patvirtintas DP leidžia prognozuoti architektūrines pasekmes miesto ịvaizdžiui ir istoriniam kontekstui; c) patvirtintas DP paremtas teritorijos (ne tik sklypo) plètros galimybių studijomis, nes DP nèra vien formali juridinè procedūra, ịteisinanti bet kokią statybą; d) patvirtintame DP nurodyti reglamentai yra pagrịsti ir realūs, t. y. DP reglamentai įrodomi projektiniais pasiūlymais, skaičiavimais, pasekmių tyrimais ir pan. Vertinant parengtus DP, prioritetu reiktų laikyti nagrinejjamų dalykų vertybinị aspektą. Pvz., Šiaulių katedros, Prisikèlimo aikštès ir gretimų teritoriju sprendiniai (ypač inicijuoti ir atlikti privačių struktūrų) negali būti vertinami tik juridiniu procedūriniu aspektu. Tai yra miesto istorinio branduolio ir velesnių urbanistinių struktūrų suderinamumo kultūrologinė problema. Daugelis detaliųjų planų yra pasenę ir nebeaktualūs, labai nekonkretūs. Tai reiškia, kad tokie planai neturi esminès įtakos miesto urbanistinès plètros procesui.

Kalbant apie Šiaulių miesto centrinès dalies urbanistines koncepcijas, neįmanoma nepaminèti St „Šiaulių planas“ 1997-2003 m. parengtų urbanistinių projektų ( 5,6 pav.). Šie projektai pasižymi ypač aukštu profesiniu lygiu, o svarbiausia - visiškai realia legitimacija. Tai reiškia, kad tuo metu buvo optimalus balansas tarp profesinès veiklos ir viešojo administravimo. Reikšmingiausias St „Šiaulių planas“ parengtas ir patvirtintas miesto taryboje projektas - Šiaulių miesto Prisikèlimo aikštès su prieigomis detalusis planas (1999) (7 pav.). Pagrindinè problema - neaiškios Priskèlimo aikštès ribos. Iki šiol egzistuoja samprata, kad aikštè yra visas neužstatytas plotas, ribojamas katedros, savivaldybès, projektavimo biurų, banko ir kitu pastatų. DP autoriai Priskèlimo aikštę traktuoja kaip nominalių erdvių sistemą - erdvè prie katedros, skveras prie savivaldybės, kurdonerine erdve prie kolegijos pastato ir pagrindinè aikštès erdvè.

$2010 \mathrm{~m}$. Šiaulių miesto savivaldybe suorganizavo Prisikèlimo aikštès sutvarkymo ir paminklo Tautos laisvès ir nepriklausomybès gynëjams idejjų kūrybines dirbtuves (Daunora 2010). Bandymai revizuoti $1999 \mathrm{~m}$. Prisikèlimo aikštès DP sprendinius rezultatų nedavè. Kartu išryškejjo keletas tendencijų, kurios būdingos visai Lietuvai: a) rimtus architektūros ir urbanistikos konkursus pakeičia neaiškaus žanro renginiai, vadinami kūrybinėmis dirbtuvėmis (workshop), tai leidžia sprendžiant rimtas problemas dalyvauti bet kam ir kalbèti bet kaip; b) profesinė argumentacija dažnai užleidžia vietą verbalinei agitacijai; c) kūrybinès dirbtuvès turi visus viešųjų ryšių akcijų požymius.

\section{Šiaulių miesto urbanistinė struktūra ir jos elementų vertybinè hierarchija}

Pagrindiniai Šiaulių miesto istorinio centro (senamiesčio) ir centrinio rajono struktūriniai elementai yra šie: a) Šiaulių miesto istorinis centras (senamiestis), kuris siūlomas kaip pagrindinis vertybių arealas (pagal Šiaulių miesto bendrojo plano koncepciją; $2007 \mathrm{~m}$.); b) senamiesčio struktūroje dominuoja pagrindinių gatvių susikirtimas (Tilžès ir Vilniaus gatvių); c) aiškiai išreikšta pagrindinè aikštè (Prisikèlimo) su šalia stovinčia katedra; d) senamiestyje dominuoja kvartalinis morfotipas, o likusioje dalyje - sodybinis. Šiauliu miesto centrinio rajono struktūriniame modelyje siūlomi urbanizaciniai ruožai faktiškai ịvertina jau įvykusius procesus.

Šiaulių miesto centrinès dalies plètros tendencijas išnagrinèjo doc. dr. I. Alistratovaitė-Kurtinaitienè daktaro disertacijoje (Alistratovaitè 2004), todèl daug tiksliau galima prognozuoti būsimus urbanistinius procesus. Siūlymai intensyviau urbanizuoti nagrinèjamą teritoriją yra logiški, nes joje nèra identifikuota jokių urbanistinių architektūrinių vertybių, o dabar vykstantys užstatymo intensyvinimo procesai yra objektyvūs ir neišvengiami. Svarbu meninès kokybės aspektas. Būtina urbanistinè koncepcija, kitokiu atveju turèsime stichinès plètros atveji. 


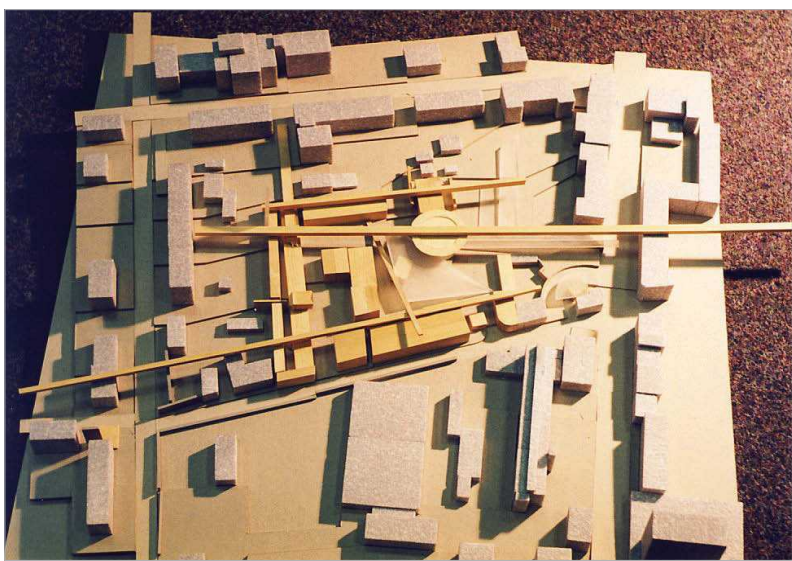

5 pav. Kvartalo tarp Vilniaus, Vasario 16-osios, Vytauto gatvių ir Draugystès prospekto detalusis planas ${ }^{26}$. SI „Šiauliu planas“, 1999. Architektai: A. Černiauskas, V. Rudokas

Fig 5. The detailed plan of the block between Vilnius, Vasario 16 and Vytautas streets and Draugystè avenue. Constructional company "Šiaulių planas", 1999. Architects: A. Černiauskas, V. Rudokas

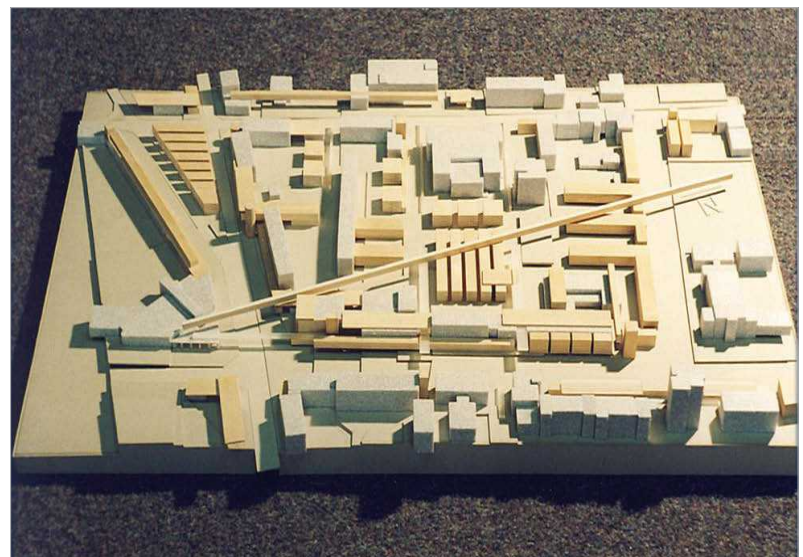

6 pav. Kvartalo tarp Vilniaus g., Kaštonų al., Aušros al. ir Žemaitès g. detalusis planas ${ }^{27}$.

SI „Šiaulių planas“, 1999. Architektai: A. Černiauskas, V. Rudokas

Fig 6. The detailed plan of the block between Vilnius, Žemaitè streets and Kaštonai, Aušra avenues. Constructional company "Šiaulių planas", 1999. Architects: A. Černiauskas, V. Rudokas
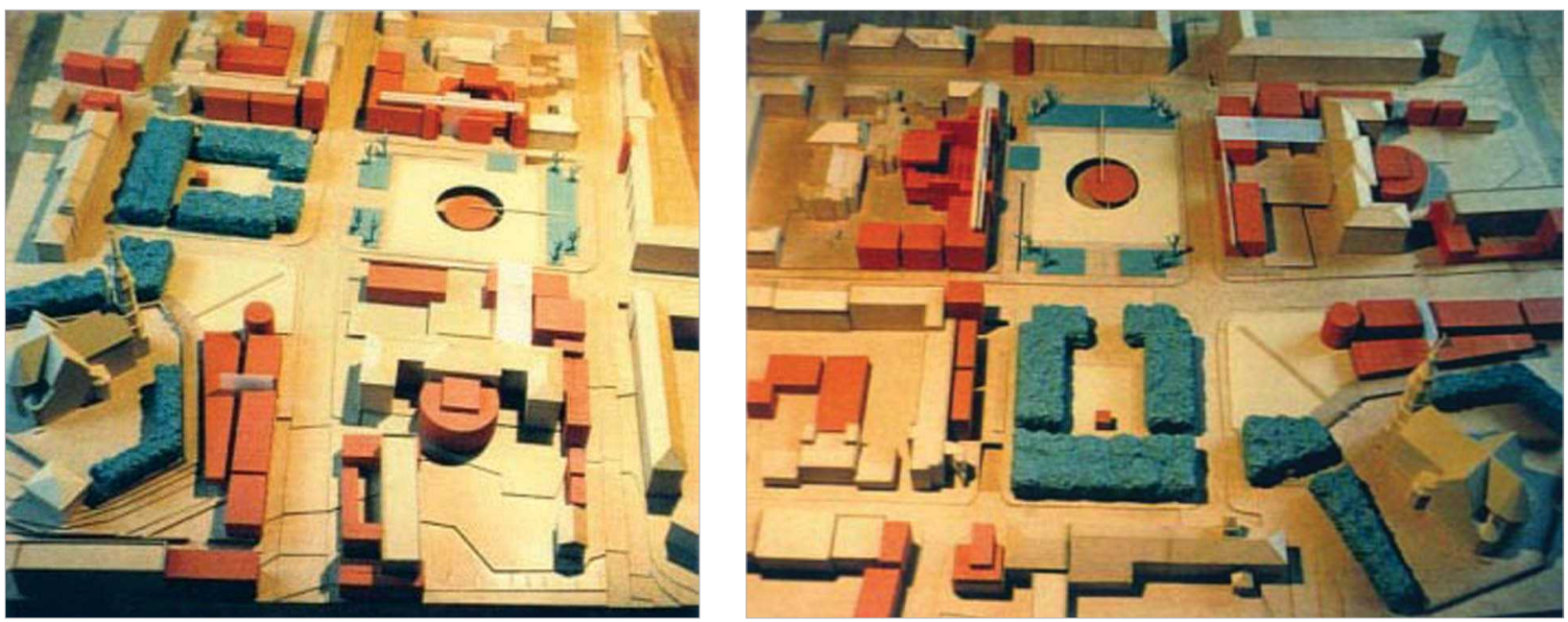

7 pav. Šiaulių miesto Prisikèlimo aikštės su prieigomis detalusis planas ${ }^{28}$. Sl „Šiaulių planas“, 1999. Architektai: A. Černiauskas, V. Rudokas, A. Vyšniūnas

Fig 7. The detailed plan of the Resurrection Square and its suroundings in Šiauliai. Constructional company "Šiaulių planas", 1999. Architects: A. Černiauskas, V. Rudokas, A. Vyšniūnas

Šiaulių miesto urbanistinèje struktūroje siūloma išskirti centrinę dalị, kurią riboja geležinkelis, Dubijos, Ežero gatvès. Pagal šią koncepciją centrinejje dalyje siūloma intensyvi urbanistinè plètra. Šiaulių miesto

\footnotetext{
${ }^{26}$ Šiaulių miesto tarybos sprendimas Nr. 222 (1999-01-14) „Dè detaliųjų planavimo projektų patvirtinimo“.

27 Šiaulių miesto tarybos sprendimas Nr. 222 (1999-01-14) „Dèl detaliųjų planavimo projektų patvirtinimo“.
}

centrinejje dalyje siūloma išskirti istorinio centro teritoriją, kuriai siūloma suteikti senamiesčio statusą. Šios teritorijos branduolys - Prisikèlimo aikštè ir katedra. Senamiestyje aukštybiniai pastatai negalimi. Užstatymas formuojamas prisilaikant „foninio“ aukš-

${ }^{28}$ Šiaulių miesto tarybos sprendimas Nr. 222 (1999-01-14) „Dèl detaliųjų planavimo projektų patvirtinimo". 
čio principo. Užstatymo tankumas ir intensyvumas priklauso nuo morfotipo. Šiaulių miesto centrinès dalies miestovaizdis priklauso nuo vizualinio identiteto zonų.

Pagrindinè išvada, kalbant apie Šiaulių miesto centrinès dalies plètros tendencijas, - rytinèje centrinès dalies pusejje (tarp geležinkelio ir Žemaitès gatvès) urbanistinè plètra yra labai komplikuota dèl labai didelio individualaus gyvenamųjų namų sektoriaus, mažų sklypų ir pan. Tokiu atveju urbanistinę plètrą lemia žemès savininkų nuosavybès santykių sistema. Naujų bendrosios miestinès paskirties objektų statymas yra vargiai įmanomas.

Išnagrinètos Vilniaus gatvès užstatymo rodiklių kitimo tendencijos Šiaulių miesto centrinès dalies plètros kontekste. Bendrą Vilniaus gatvès plètros tendenciją galima ịvardinti tokia seka: užmiesčio gatvè priemiestis - centrinès dalies gatvè. Senųjų Šiaulių miesto planų analizè parodè, kad rytiné planuojamos teritorijos dalis pradèta intensyviai urbanizuoti tik po II pasaulinio karo. Užstatymo tankumo kitimas nagrinejjamoje teritorijoje - nuo $6 \% 1942 \mathrm{~m}$. iki $14 \% 2002 \mathrm{~m}$. Didejjimo tendencija akivaizdi, bet rodiklis vis tiek yra labai mažas. Užstatymo intensyvumo kitimas nagrinèjamoje teritorijoje - nuo 0,06 $1942 \mathrm{~m}$. iki 0,14 $2002 \mathrm{~m}$. Rodiklis yra labai mažas. Užstatymo vidutinio aukštingumo kitimas nagrinejamoje teritorijoje - nuo 1,0 aukšto $1942 \mathrm{~m}$. iki 1,1 aukšto $2002 \mathrm{~m}$. Rodiklis yra labai mažas. Tokie žemi Vilniaus gatvės užstatymo rodikliai (tankumas, intensyvumas, vidutinis aukštingumas) rodo, kad teritorija eksploatuojama labai neefektyviai.

\section{Šiaulių miesto centrinès dalies erdvinès struktūros vystymo idèja}

Visų pirma turi būti aiškiai apsispręsta dèl principinių plètros nuostatų, t. y. arba plètra vykdoma ekstensyviai (naujai užstatomose teritorijose) arba miestas tankinamas (Pakalnis 2000). 2007 m. sausio mèn. Šiaulių miesto Taryba patvirtino bendrojo plano erdvinę koncepciją, kurioje siūloma intensyvinti užstatymą miesto centrineje dalyje.

Užstatymas tankinamas gali būti ịvairiais būdais, todèl tikslinga kalbèti apie tyrimų metodikas, metodinius principus, procesu valdymo principus, vertinimo kriteriju prioritetus ir pan., taigi pagrindiniai miesto erdvinès struktūros vystymo principai siūlomi: a) centrineje Šiaulių miesto dalyje būtina apibrěžti teritoriją, kurią galima būtų traktuoti kaip senamiestị. Tokia struktūra turi nedaug teritorinių rezervų, todèl ji tobulètų iš vidaus, t. y. intensyvètų visi rodikliai.
Senamiestyje ypač aktuali fizinès erdvès kokybès problema. Būtina atgaivinti istoriškai susiklosčiusį erdvinị karkasą; b) masinès statybos gyvenamieji rajonai yra daugiau socialinè problema negu architektūrinè. Juose konversija artimiausiu metu nę̇manoma, ypač teritorijų, labai nutolusių nuo istorinio centro; c) pastatų, pastatytu pagal tipinius projektus miesto centrineje dalyje, likimas priklauso nuo strateginès padeties ir atitinkamai nuo žemès kainos.

Užstatymo architektūrineje urbanistinejje koncepcijoje turi būti ịvertintos gretimos teritorijos, t. $y$. būtina visos teritorijos erdvinè koncepcija. Siūloma tokia teritorijos užstatymo architektūrinè urbanistinè koncepcija: pagal galimybes projektuoti kuo daugiau ivairių tipų namų ir butų, t. y. vengti vienos paskirties ir vieno tipo pastatų.

Šiauliuose labai silpnai išreikštas istorinis centras, t. y. miesto struktūrinis branduolys. Reprezentacinio centro, kitaip tariant, senamiesčio ribos yra neidentifikuotos. Todèl prioritetitinis uždavinys - identifikuoti senamiesčio struktūrines ribas ir jas juridiškai užfiksuoti kaip saugomas kultūros paveldo teritorijas. Miesto kompozicija yra susijusi su nauju teritoriju erdvine kompozicija. Pagrindinis struktūrinis branduolys - miesto centras (senamiestis). Miesto centro kompozicijos vientisumas priklauso nuo morfotipu kokybės ir jų užbaigtumo.

Kalbant apie miesto vizualinị identitetą būtina sukurti miesto panoramų ir silueto apžvalgos taškų sistemą, kuri padètų apibrèžti vizualinio identiteto zoną. Kartu reikia identifikuoti pačius vertingiausius vaizdus ir vaizdo elementus, kuriuos būtina saugoti. Vizualinio identiteto zona turi prasmę, jeigu yra apibrèžtos labai aiškios senamiesčio ribos.

\section{Išvados ir rekomendacijos}

1. Norint igyvendinti Šiaulių miesto bendrojo plano nuostatą - respektuoti senąją miesto dalị, būtina identifikuoti urbanistinès struktūros vertingąsias savybes, kartu îvertinus urbanistinès plètros potencialą. Subalansavus urbanistinès plètros ir urbanistikos paveldo apsaugos sistemą, reikia parengti rekomendacinių užstatymo principų ir rodiklių kompleksą, pagal kurị galima būtų rengti Šiaulių miesto centrinès dalies detaliojo plano (DP) reglamentus. Esamos padèties analizè apima du pagrindinius blokus: a) kiekybinị statistinị (žemès nuosavybès sistema; žemès naudojimo pobūdis; užstatymo tankumas, aukštingumas, intensyvu- 
mas ir t. t.) ir b) kokybinį (urbanistinès struktūros ir architektūrinių objektų bei ansamblių kompoziciniai ypatumai; miesto erdvinis karkasas; vizualinis identitetas ir t. t.). Kadangi Šiauliuose nèra veiksmingos planavimo procesų monitoringo sistemos, neįmanoma kalbèti apie bendras urbanistinès plètros tendencijas. Todèl egzistuoja paklaidos galimybè, nes statistiniai duomenys pateikti tik konkrečiam momentui, o ne urbanistinès plètros procesui. Kokybinio analizès aspekto pagrindinis kriterijus - istoriškai susiklosčiusi urbanistine struktūra (gatvių tinklas, erdvinis karkasas ir pan.), todèl kuriant DP koncepciją rekomenduojama didesnį dèmesį skirti fundamentinèms urbanistikos problemoms, metodikoms, principams, o ne susitelkti tik ties juridinemis procedūromis.

2. Egzistuoja reali problema - neidentifikuota Šiaulių miesto centrinès dalies ir senamiesčio samprata. Neaišku, apie kokią konkrečiai teritoriją kalbama. Šiaulių miesto centrinè dalis įvairiais laikotarpiais buvo įvairiai traktuojama. 2009 m. patvirtintame Šiaulių miesto bendrajame plane kalbama apie Šiaulių miesto senamiestị. Tai yra istoriškai susiklosčiusi teritorijos dalis, kurios buvimo faktas identifikuoja iš esmès naują Šiaulių miesto urbanistinès struktūros kokybès etapą. Senamiestis yra Šiaulių miesto centro dalis. Todèl reikia aiškiai skirti terminus - Šiaulių miesto centrinis rajonas (apima senamiestị, individualių gyv. namų rajonus ir istorinius priemiesčius), senamiestis (vertingiausia miesto urbanistinès struktūros dalis su pagrindine aikšte), Šiaulių miesto centrinė dalis (planuojama teritorija), Senojo miesto riba (Šiauliu miesto užuomazga).

3. Šiaulių miesto centrineje dalyje yra labai daug individualaus sodybinio tipo užstatymo, kuris aiškiai yra neadekvatus teritorijos statusui miesto urbanistinëje struktūroje, nes šioje teritorijoje visiškai nèra centro funkcijų. Urbanistinè plètra individualių gyv. namų rajonuose, esančiuose miesto centrinejje dalyje, yra labai komplikuota dèl labai sudètingos žemès nuosavybès struktūros, nedidelių sklypų. Pagrindinè urbanistinès plètros ir urbanistinių vertybių apsaugos sistemos konfliktų zona - senamiestis ir konversinès teritorijos istorineje miesto dalyje. Reikia skirti miesto teritorijos geometrini centrą nuo istorinio centro, nes tai iš esmès skirtingi morfologiniai vienetai, nors Šiaulių miesto atveju dalis teritorijų persidengia.
4. Šiaulių miesto urbanistinès struktūros istorinès raidos analizè atlikta rengiant DP koncepciją, remiantis istoriografine medžiaga. Ši analizè nepretenduoja ị išsamią istorinę studiją, bet yra tikslinga parodyti Šiaulių miesto urbanistinès struktūros ir architektūrinių objektų bei ansamblių ypatumus, akcentuojant jų vertingąsias savybes. Senų nuotraukų analizè parodè, kad Šiauliuose dar yra ženklų, kurie leidžia atpažinti senąją struktūrą. Šios struktūros „reabilitacija“ yra pirmaeilis uždavinys. Šiaulių miesto istorinio formavimosi etapų analizė (pagal istorinius miesto planus) parode miesto teritorinès plètros etapus tam tikrais periodais, $t$. $y$. atsispindi miesto teritorijos augimo tendencijas. Erdvinè kokybė neidentifikuota, todèl analizuoti jau nepriklausomybès laikais parengti projektai, galimybių studijos ir t. t. Norint tiksliau apibrèžti prognozuojamus planavimo principus reikia miesto centrinę dalị išnagrinèti pagal miesto morfologijos kriterijų.

5. Šiaulių miesto centrinès dalies plètros tendencijas išnagrinejo doc. dr. I. Alistratovaitè-Kurtinaitienè savo daktaro disertacijoje (VGTU Urbanistikos katedra, 2004), todèl daug tiksliau galima prognozuoti būsimus urbanistinius procesus. Siūlymai intensyviau urbanizuoti miesto centrinès dalies teritoriją būtų logiški, nes joje nèra identifikuota jokių ypatingų urbanistinių architektūrinių vertybių, o dabar vykstantys užstatymo intensyvinimo procesai yra objektyvūs ir neišvengiami. Svarbu meninès kokybės aspektas. Būtina urbanistinè koncepcija, kitokiu atveju turèsime stichinès plètros atveji. Žemi užstatymo rodikliai (tankumas, intensyvumas, vidutinis aukštingumas) rodo, kad teritorija eksploatuojama labai neefektyviai.

6. Šiaulių miesto centrinès dalies erdvinio kompozicinio karkaso analizè ir erdvinès struktūros vystymo strategija. Tikslinga kalbėti apie tyrimų metodikas, metodinius principus, procesų valdymo principus, vertinimo kriteriju prioritetus ir pan., todèl pagrindiniai miesto erdvinès struktūros vystymo principai siūlomi: a) centrinèje Šiaulių miesto dalyje būtina apibrèžti teritoriją, kurią galima būtų traktuoti kaip senamiestį. Tokia struktūra turi nedaug teritorinių rezervų, todèl ji tobulètų iš vidaus, t. y. intensyvètų visi rodikliai. Senamiestyje ypač aktuali fizinès erdvès kokybès problema. Būtina atgaivinti istoriškai susiklosčiusị erdvinị karkasą; b) masinès statybos gyvenamieji kvartalai se- 
namiestyje yra daugiau socialinè problema negu architektūrinè. Juose konversija artimiausiu metu neįmanoma; c) pastatų, pastatytų pagal tipinius projektus miesto centrinèje dalyje, likimas priklauso nuo strateginès padeties ir atitinkamai nuo žemès kainos.

7. Šiaulių miesto centrinei daliai (ypač senamiesčiui) didelę įtaką daro teritorija tarp Talšos ežero, Prūdelio ir Rekyvos ežero, kuri yra Šiaulių Tytuvėnų apskalautų moreninių gūbrių ir pelkètų duburių kompleksas (Bagdonaite 2007). Nepaisant to, šioje teritorijoje jau daugiau kaip $100 \mathrm{~m}$. stovi Ch. Frenkelio fabriko kompleksas. Pramonine funkcija yra istorinis faktas. Šioje teritorijoje urbanizaciniai procesai yra jau ịvykęs faktas (garažai, automobilių servisas, individualūs gyv. namai), todèl tolesnè urbanizacija yra iš principo leistina. Svarbu nustatyti optimalų leistiną urbanizacijos laipsni. Nors Šiaulių miesto bendrojo plano koncepcijoje nagrinejjama teritorija patenka $\mathfrak{i}$,žaliosios jungties" zoną, bet tai nereiškia, kad šioje teritorijoje galioja "grynosios gamtos“ kriterijai. Svarbu nustatyti tinkamą proporciją tarp urbanizuojamų teritorijų ir viešųjų erdvių. Formuoti naujų sklypų nerekomenduojama. Ši teritorija yra rekreacinè zona centro gyventojams.

\section{Literatūra}

Alistratovaitè, I. 2004. Morfologinès struktūros transformacijos centriniame miesto rajone (Lietuvos pavyzdžiu): daktaro disertacija. Humanitariniai mokslai, menotyra $(03 \mathrm{H})$, skulptūra ir architektūra (H312). Vilnius: VGTU.

Archiforma 4. 2002.

Bučas, J. 1995. Urbanistikos paveldo saugotinos teritorijos, Urbanistika ir architektūra 1-2(19-20): 157-172.

Butkus, T. S. 2010. Šiauliu miesto Prisikèlimo aikštè (aikštès sutvarkymo ir paminklo Tautos laisves ir nepriklausomybès gynèjams ideju kūrybinès dirbtuvès). Kaunas: Kitos knygos.

Bagdonaite, D. 2007. Šiauliu miesto gamtinis karkasas. Žaliuju plotu plètojimo koncepcija. Šiauliu m. bendrojo plano koncepcija. Šiauliai: UAB „Urbanistika“.

Čepaitienè, R. 2009. Interpretuojant daugiakultūrị Vilnių: kontekstai, problemos ir galimybès, iš Naujasis Vilniaus perskaitymas: didieji Lietuvos istoriniai pasakojimai ir daugiakultūrinis miesto paveldas: straipsnių rinktinè. Vilnius: VU leidykla, 50-77.

Daunora, Z. J. 2010. Brandinama Šiauliu miesto Prisikèlimo aikštės sutvarkymo idejja, Urbanistika ir architektūra 34(2): I a-I d.

Lietuvos architektūros istorija. Nuo XVII a. vidurio iki XIX a. vidurio (II tomas). 1994. Vilnius: Mokslo ir enciklopedijų leidykla.
Lietuvos urbanistikos paveldas: vertybiu ịteisinimas, apsauga, tvarkymas (1967-1993): dokumentų rinkinys. 2005. Sudare, pratarmę ir paaiškinimus parašè A. Miškinis. Vilnius: Savastis.

Neniškis, E. 2002. Visuomeniniu procesu įtakos miesto ir regiono erdvinei struktūrai dèsningumai ir ju modeliavimas: daktaro disertacija. Humanitariniai mokslai, menotyra (03H), skulptūra ir architektūra (H312). Vilnius: VGTU.

Pakalnis, M. 2000. Miestų užstatymo tankinimo metodikos parinkimas ir Vilniaus Naujamiesčio tankinimo programa, Urbanistika ir architektūra XXIV(4): 149-162.

Puronas, V. 2009. Saules miesto veidas (Dizaineris apie Šiauliu pramonę. Idomioji Šiauliu istorija). Šiauliai: Šiaulių universiteto leidykla.

Senieji Šiauliai atvirukuose. 2006. Katalogas. Šiaulių „Aušros“ muziejus.

Šešelgis, K. 1996. Lietuvos urbanistikos istorijos bruožai (nuo seniausiu laiku iki 1918 m.). Vilnius: Mokslo ir enciklopedijų leidykla.

Vyšniūnas, A. 2002. Šiaulių miesto bendrojo plano priešprojektiniai darbai (tyrimai). Išorinè struktūra (priemiesčiu planavimas) ir miesto struktūra (urbanistinè dalis). Siauliai.

Vyšniūnas, A. 2000. Fizinio erdvès formavimo problemos, rengiant Šiaulių miesto pagrindinès aikštės ir jos prieigų detalųji planą, Urbanistika ir architektūra XXIV(4): 163-170.

Vyšniūnas, A. 2002. Šiauliai ir Panevėžys; žingsnis po žingsnio, Archiforma (4): 23-26.

Vyšniūnas, A. 2007a. Šiaulių miesto bendrasis planas. Teritorijos vystymo koncepcija (pirma straipsnio dalis), Nauja statyba 2(24): 66-70.

Vyšniūnas, A. 2007b. Šiaulių miesto bendrasis planas. Teritorijos vystymo koncepcija (antra straipsnio dalis), Nauja statyba 3(25): 54-58.

\section{THE CENTRAL PART OF ŠIAULIAI OR TERRITORY WITH AN URBAN HERITAGE STATUS?}

\section{A. Vyšniūnas}

Abstract. On 27 January 1969 the list of urban heritage in Lithuania was officially declared, and therefore 62 cities and towns, with the exception of Šiauliai, were given the status of local Lithuanian urban values. In 1980 the revised list of Lithuanian urban heritage again disregarded Šiauliai. But the analysis of the current situation, estimating demands of urban development, has demonstrated the existence of a very clear historic urban structure in Šiauliai, which can be regarded as a valuable urban heritage territory. A lot of scientific research projects, urban planning documents, architectural and urban competitions strengthened an urban heritage argument with facts. The ways of legitimating an urban heritage status are obvious. The potential of urban development in the central part of Šiauliai is enormous, but a balance between urban deveploment and urban heritage conservation and preservation is also very important.

The paper applies scientific statistical data and information received from the urban concept of Šiauliai and the analysis of 
the current urban structure. The information of the paper can be applied for creating a recommendable indicator system and urban development principles during the detailed planning process in Šiauliai.

Keywords: historic urban heritage, old town, detailed plan of the central part of Šiauliai, urban development

\section{ALGIS VYŠNIŪNAS}

Prof., Dept of Urban Design, Vilnius Gediminas Technical University (VGTU), Pylimo g. 26/Traku g. 1, 01132 Vilnius, Lithuania,E-mail: algis.vysniunas@gmail.com

Teaching: lectures on architectural design, urban planning composition, reconstruction of the city environment and urban structure. Publications: author of about of 20 scientific works and research projects, including "The reconstruction of city living structures", co-author of a monograph "Preservation of visual identity of Vilnius city and principles of its development" (2004). Research interests: spatial layout structure of towns and districts, urban structure and morphology. 